\title{
Batman Kentinde Mekânsal Büyümenin Arazi Kullanımına Etkisi*
}

\author{
Adnan ALKAN** \\ Siirt Üniversitesi, Fen-Edebiyat Fakültesi, Coğrafya Bölümü, Siirt, TÜRKIYE
}

\begin{tabular}{|c|c|}
\hline Geliş Tarihi/Received: 20.07.2018 & Kabul Tarihi/Accepted: 18.10 .2018 \\
\hline \multicolumn{2}{|l|}{$\overline{\text { ORCID ID }}$} \\
\hline (DD) orcid.org/0000-0002-5377-4726 & \\
\hline
\end{tabular}

Öz: Kentsel alanların mekânsal büyümesi ve gelişmesiyle birlikte, kentsel arazi kullanım içerisinde köklü değişiklikler meydana gelmektedir. Kentsel büyüme planlı ve kontrollü bir şekilde gerçekleşmediği takdirde çevre kirliliği başta olmak üzere, çarpık ve düzensiz yapılaşmaya, tarım arazilerinin şehir içerisinde kalmasına ve vasıflarını yitirmesi vb. çeşitli olumsuzluklara yol açmaktadır. Türkiye'de özellikle 1980'li yıllar ve sonrasında yaşanan kentsel büyüme ülke geneline hızlı bir şekilde yayılmıştır. Bu bağlamda Türkiye'de hızlı kentleşme ve sanayileșme yaşayan kentlerden biri olan Batman araștırma konusunu oluşturmaktadır. Bu çalışmada hızlı şehirleşme süreci yaşayan Batman kentinin 1985 ve 2016 yıllarına ait uydu görüntüleri kullanılarak kent ve çevresinde arazi kullanımı nasıl bir gelişme gösterdiği belirlenmiştir. Buna ek olarak 19852016 yılları arasındaki süreçte şehirsel gelişim alanı içerisinde arazi kullanım sınıflamasına göre şehrin hangi alanlar üzerinde ne kadar genişlediği belirlenmiştir. Batman kentinin kentsel gelişimini ve kentin arazi kullanım sınıflamasını belirlemek için 1985 ve 2016 yıllarına ait Landsat TM ve OLI uydu görüntüleri kullanılmıştır. 1985 ve 2016 yıllarına ait kentsel alana dönüşen arazi sınıfları değişimleri analiz edilerek saptanmıştır. Çalışmanın sonucunda elde edilen tüm arazi sınıflarından yerleşime doğru bir dönüşümün olduğu belirlenmiştir. Nitekim 1985 ve 2016 yıllarına ait uydu görüntüleri temel alınarak yapılan analizler neticesinde Batman kentinin 30 yıllık süreçte 1730 hektar büyüyerek, yaklaşık \% 167 oranında mekânsal genişleme sağladığı anlaşıılmaktadır. Buna karşın kuru tarım arazileri ise 30 yıllık süreçte yaklaşık 2400 hektar azalmış ve \% 20'ye yakın bir kayıp yaşamıştır.

Anahtar Kelimeler: Batman, arazi kullanımı, mekânsal büyüme, coğrafi bilgi sistemleri

\section{Impact of Spatial Growth on Land Use in Batman City}

\begin{abstract}
Along with the spatial growth and development of urban areas, fundamental changes in urban land use have been taken place. If urban growth does not take place in a planned and controlled manner, there are various problems such as environmental pollution, crooked and irregular build-up, agricultural land stays in the city and the loss of qualifications. The urban growth observed in Turkey especially in the 1980s and afterwards spread rapidly throughout the country. In this context, in this study, Batman city which is one of the cities where rapid urbanization and industrialization seen in Turkey is being investigated. In this study, it was determined how Batman City, which is experiencing rapid urbanization process, has improved its use of the land in and around the city by using satellite images of 1985 and 2016 years. In addition, in the period between 1985 and 2016, it was determined how much the city expands according to the land use classification within the urban development area. Landsat TM and OLI satellite images of 1985 and 2016 were used to determine urban development of Batman City and urban land use classification. It has been determined that there is a conversion to settlement from all terrain classes obtained as a result of the work. As a result of the analyses made on the basis of the satellite images of the years 1985 and 2016, Batman has grown by 1730 hectares over a 30-year period and achieved a spatial expansion of about $167 \%$. On the other hand, in the 30 -year period, the dry agricultural lands decreased by approximately 2400 hectares and experienced a loss of close to $20 \%$.
\end{abstract}

Keywords: Batman, land use, spatial growth, geographic information systems

\footnotetext{
": Bu çalışma, Türk Coğrafya Kurumu tarafından 8-10 Kasım 2017 tarihlerinde Ankara'da düzenlenen 75. Yıl Uluslararası Kongresi'nde sözlü bildiri olarak sunulmuș olup özeti yayınlanmıștır.
} 


\section{Giriş}

Kentleşme, belirli bir süre içinde genel nüfusun herhangi bir kritere göre kent olarak kabul edilmiş olan yerleşmelerde yaşayan oranının yükselmesi şeklinde gerçekleşmektedir (Keleş, 1961; Tümertekin, 1973). Esas itibariyle kentleşme Büyük Sanayi Devrimi ile meydana gelen, sanayinin başrolü oynadığı ve buna paralel olarak bütün dünyaya yayılan bir olgudur. Başlangıçta Batı Avrupa ülkelerinde ortaya çıkan ve daha sonra bütün dünyayı etkileyen ve yaklaşık 200 yıldır devam eden kentleşme olayı, bütün dünyada üretim kalıplarını, sosyo-ekonomik düzeni ve insanoğlunun yeryüzündeki mekânsal dağılım düzenini baştan aşağıya değiştirmiştir. Kentleşme ile birlikte kırlar boşalırken, kentler ise nüfusun yığgldığg mekânlar haline dönüşmüştür (Aliağaoğlu ve Uğur, 2016). Bunun yanında Dünyada kentleşmenin en yüksek olduğu ülkeler gelişmiş olanlar iken, kentleşmenin en hızlı yaşandığı ülkeler ise gelişmekte olanlardır. Türkiye'de de gelişmekte olan ülkelerdekine benzer bir kentleşme hızı bulunmaktadır (Çavuş, 2007; Karakuyu ve ark., 2012; Keleş, 2013).

Esasen kentleşme ve kentlerin alansal büyümesi en fazla tarım arazilerini ve bu arazilerin amaç dışı kullanımını etkilemektedir (Özügül, 2010; Sönmez, 2012). Bu da kentsel büyümenin dikkatli bir şekilde izlenmesi gerekliğini açıkça göstermektedir (Seydanlıoğlu ve Turgut, 2017). Kentleşmeye bağlı olarak ortaya çıkan konut, sanayi ve ticaret alanları ile sağlık, hizmet, güvenlik ve ulaştırma amaçlı arazi kullanım sahaları, en önemli kentsel arazi kullanımları olarak göze çarpmaktadır. Özellikle konut sahaları, sanayi tesisleri, iş, ticaret ve alışveriş merkezleri, karayolları, havaalanları, otogarlar, üniversite kampüsleri, organize sanayi bölgeleri, hastaneler, akaryakıt istasyonları, toplu konut projeleri, kültürel tesisler, kentlerin alansal büyümesini ve gelişim doğrultularını en fazla etkileyen kentsel kullanımlardır (Keleş, 2013). Söz konusu kentsel birimlerin ihtiyacını karşılayacak en elverişli araziler kentlerin çevresinde bulunduğu için kentlerin etrafındaki tarım arazileri hızla bu kullanımlar için işgal edilmektedir. Dolayısıyla bu kent birimleri tarım alanlarının işgal edilmesini hızlandıran temel unsurlar olarak karşımıza çıkmaktadır (Özcanlı ve ark., 2018).

Özellikle sanayi ve ticaret alanları kent yerleşmelerinin alansal olarak büyümesini en çok hızlandiran fonksiyonlar olup, bu alanlar çoğunlukla verimli tarım arazileri üzerinde kurulmaktadır. Bunun yanında kentlerin çevresindeki orman ve mera sahaları da, artan nüfus baskısı nedeniyle hızla tarıma açılmaktadır. Böylece kentleşme, kentlerin yerleştikleri araziyi ve yakın çevresini hızla değiştirerek, bu arazilerin nitelik kaybına uğramasına ve vasfını yitirmesine yol açmaktadır. (Kızılelma ve ark., 2013, Dengiz ve Demirağ Turan, 2014).

Sürdürülebilir kalkınmayı sağlamak ve çevreyi korumak adına arazi kullanımında meydana gelen değişimlerin sürekli ve düzenli aralıklarla izlenmesi, olaylara zamanında müdahale etme açısından son derece önemlidir. (Gürün ve Doygun, 2006; K1z1lelma ve ark., 2013, Bayar ve Karabacak, 2017). Kentleşme açısından dünya ortalamasının üzerine çıkmış olan Türkiye'de, gelecekte daha planlı ve sürdürülebilir kentler için kentleşmenin izlenmesi ve planlamaların bu doğrultuda yapılması daha doğru olacaktır (Kaya ve Toroğlu, 2015).

Diğer yandan arazi kullanım değişim eğilimlerinin tahmin edilmesi kent planlamasının en önemli konularından birini oluşturmaktadır. Ancak, kent sisteminin birçok bilinmeyen faktör içermesi ve karmaşık yapısı nedeniyle, kentsel gelişimin tahmin edilmesi bilimsel bir anlayış olmadan oldukça zordur. $\mathrm{Bu}$ bağlamda Coğrafi Bilgi Sistemleri (CBS), Uzaktan Algilama (UA) ve özellikle de karmaşık ve doğrusal olmayan teorilerde meydana gelen hızlı gelişmeler yeni modellerin oluşturulmasını sağlamıştır. $\mathrm{Bu}$ teknolojik gelişmeler sayesinde karmaşık kentsel sistemlerin zamansal ve mekânsal ölçekte değişimi, bu değişiminin yönü analiz edilebilir hale gelmiştir (Aydın, 2015). Özellikle 1972 yılından sonra yergözlem uydularından elde edilen görüntüler, 1980'li yıllardaki bilişim teknolojilerindeki gelişmeler, UA teknikleri ve coğrafi bilgi sistemlerinin gelişmesine katkıda bulunmuştur. $\mathrm{Bu}$ yöntem ve tekniklerin hızının ve güvenirliğinin yüksek olması gibi nedenlerle dünyada ve Türkiye'de UA ve CBS teknikleri kullanılarak arazi kullanım değişimi ile ilgili ayrıntılı çalışmalar yapılmasına neden olmuştur (Kara ve Karatepe, 2012; Inouye ve ark., 2015; Kaya ve Toroğlu, 2015; Adhikari ve Hansen, 2018).

Bu çalışmanın amacı Türkiye'nin gerek petrole dayalı sanayi faaliyetleri açısından, gerekse küçük bir köy yerleşmesi iken petrol sayesinde son 50 yılda hızla büyüyerek, büyük bir yerleşmeye dönüşen kentlerden biri olan Batman'ın kentsel gelişimini belirlemek ve bu gelişimin arazi kullanımı açısından meydana getirdiği değişiklikleri ortaya koymaktır.

\section{Materyal ve Yöntem}

\subsection{Batman kentinin konumu}

Batman kenti, Güneydoğu Anadolu Bölgesi’nde Diyarbakır Havzası'nın güneydoğu bölümünde yer almaktadır (Şekil 1). Batman ilinin yönetim 


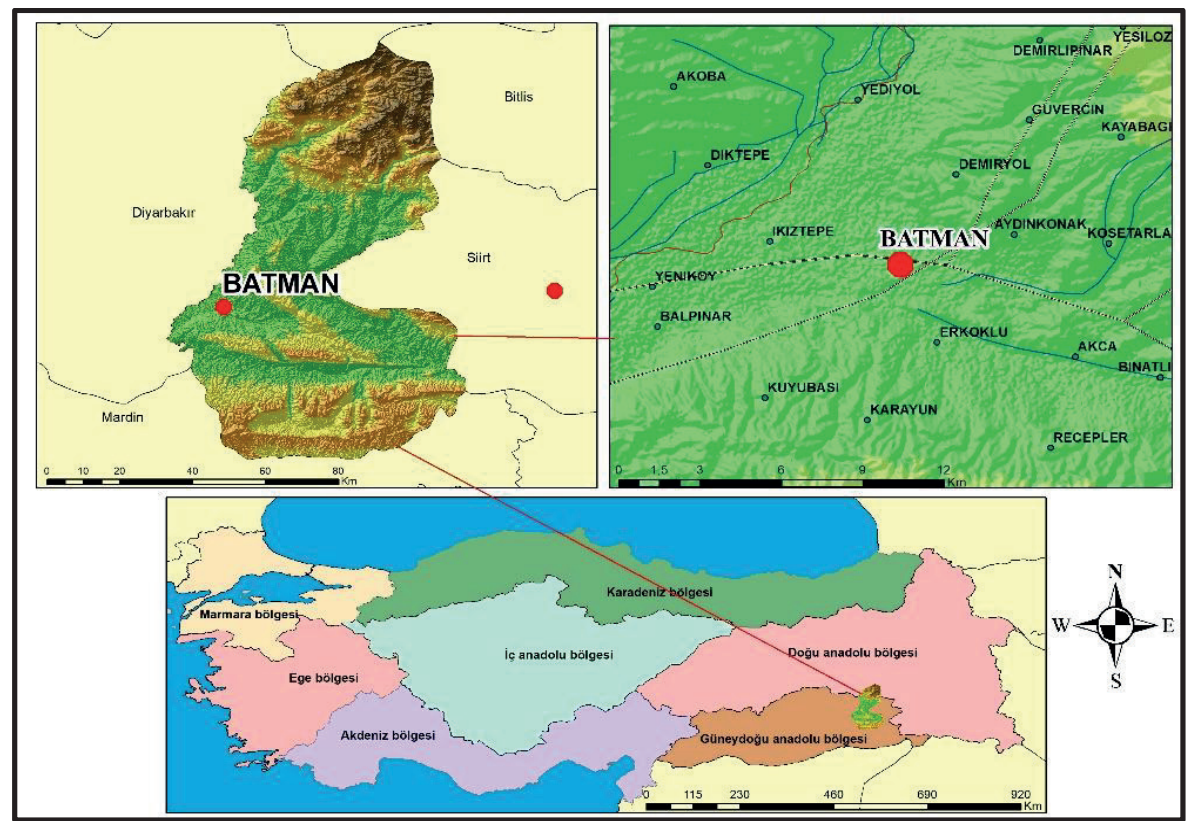

Şekil 1. Çalışma sahası lokasyon haritası

merkezi durumunda olan kent, Batman Çayı'nın eski menderes yeniği sekileri üzerinde kurulmuş olup, petrole bağlı olarak hızla gelişerek Tilmis Ovası'nın kuzeybatı bölümünü kaplamıştır (Tonbul ve Sunkar, 2008). Raman Dağı'nın kuzeyindeki verimli bir ovanın kenarına yayılan Batman, yerleştiği depresyon içinde gelişimini kuzey ve doğu yönünde gerçekleştirmiştir. Ancak özellikle son yıllarda yerleşme batıya yani ovaya doğru kaymaktadır. Kentin batısında verimli tarım alanlarının varlığı alansal gelişmeyi bu yönde desteklemektedir (Alkan ve ark., 2017). Batman kentinin batısında Bismil ilçesi (Diyarbakır), kuzeydoğusunda Silvan ilçesi (Diyarbakır) ile Kozluk ilçesi (Batman), doğusunda Batman'ın Beşiri, güneydoğusunda Hasankeyf ve güneyinde ise Gercüş ilçeleri yer almaktadır. Batman Ovası üzerinde kurulmuş olan Batman'ın, hemen batısında Batman Çayı ve yaklaşık $10 \mathrm{~km}$ güneyinde ise Dicle Nehri yer almaktadır. Kentin yakın çevresinde ise birkaç küçük akarsu bulunmakla beraber kent açısından en önemlilerinden biri kenti ikiyi bölerek akan İluh Deresi'dir (Şekil 2).

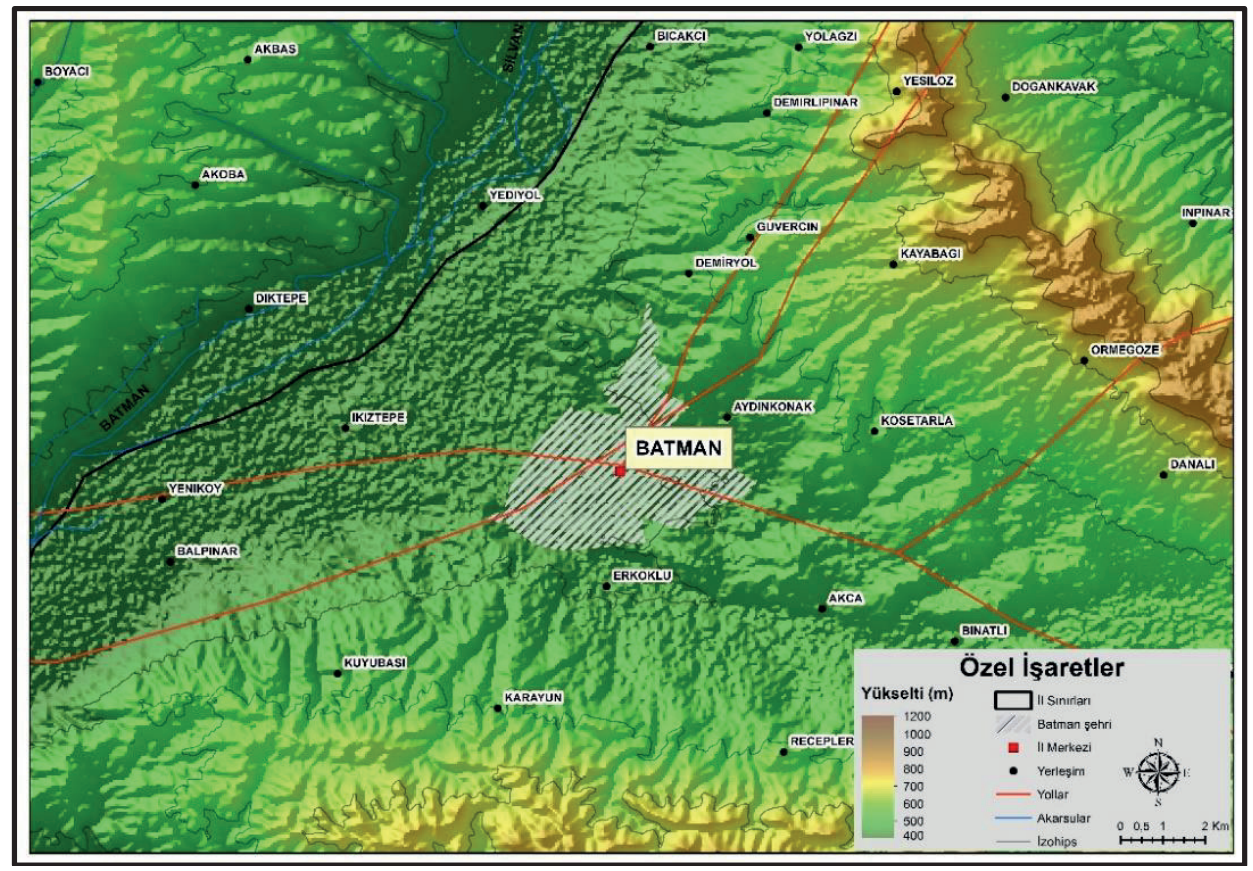

Şekil 2. Batman kenti ve yakın çevresinin topografya haritası 


\subsection{Batman kentinin genel yerleşme özellikleri}

Batman kenti, 1940'lara kadar İluh adında küçük bir köy yerleşmesi iken, Raman Dağı'nda petrolün bulunmasıyla birlikte hızla gelişerek, 1955 yılında belediyelik, 1957'de ilçe merkezi ve 1990 yılında ise il merkezi haline getirilmiştir (Sunkar ve Tonbul, 2010). Petrol çıkarımı ve ilk rafinerinin kurulmasıyla gelișen İluh köyü 1955 yılında Batman adını almış ve Türkiye'nin en hızlı büyüyen kentlerinden birine dönüşmüştür. Genel nüfus sayımlarına göre Batman'da nüfus sürekli ve çok hızlı bir şekilde artmıştır. Nitekim 1945 yılında 443 nüfusa sahip olan yerleşme, 2017 yılında 411251'lik bir nüfus büyüklüğüne ulaşmıştır (Tablo 1). Dolayısıyla küçük bir köy yerleşmesinden büyük bir kente dönüşen Batman, yaklaşık 70 yıllık kentleşme sürecinde nüfusunu bin kat arttırmayı başarmıştır.

Tablo 1. Batman kentinin sayım yıllarına göre nüfus miktarı ve nüfus artış hızı (1935-2017) (Anonim, 2018)

\begin{tabular}{ccccc}
\hline Sayım yılı & Erkek & Kadın & Toplam & Yillik nüfus artış hız (\%) \\
\hline 1935 & & & 319 & 5.6 \\
1940 & 218 & 191 & 409 & 1.7 \\
1945 & 215 & 228 & 443 & 10.3 \\
1950 & 495 & 420 & 915 & 83.0 \\
1955 & 2497 & 2216 & 4713 & 32.6 \\
1960 & 6668 & 5733 & 12401 & 20.3 \\
1965 & 13462 & 11528 & 24990 & 16.0 \\
1970 & 23484 & 21507 & 44991 & 8.6 \\
1975 & 34021 & 30363 & 64384 & 6.8 \\
1980 & 44169 & 42003 & 86172 & 5.5 \\
1985 & 56063 & 53973 & 110036 & 6.8 \\
1990 & 75499 & 71848 & 147347 & 13.5 \\
2000 & 123927 & 122751 & 246678 & 6.4 \\
2017 & 163179 & 161841 & 325020 & 5.3 \\
\hline
\end{tabular}

Batman'da kentleşme hareketleri, kendi içerisinde önemli farklılıklar arz etmektedir. Kentsel gelişimin başlangıç dönemini oluşturan 1940-1955 devresinde petrol aramaları ve ilk rafinerinin kurulmasıyla gelişmeye başlayan Batman, bu süreçte yoğun bir işçi göçü almıştır. Nitekim 1950'li yılların başında yerleşme nüfusu yıllık ortalama \% 83 civarında büyük bir artış göstermiştir. $\mathrm{Bu}$ dönemde Türkiye Petrolleri Anonim Ortaklığı (TPAO) öncülüğünde büyümeye başlayan kentte, istihdama dayalı bir kentsel büyüme trendi ortaya çıkmıştır. Kent 1957 yılında kazandığ1 yeni idari statüsüyle birlikte gelişim hızını devam ettirmiş ve 1980'li yılların başına kadar TPAO'dan kaynaklı kalifiyeli işgücü hareketliliğinin görüldüğü ve nispeten planlı bir gelişimin gerçekleştiği bir süreci yaşamıştır. $\mathrm{Bu}$ köyden şehre dönüşümün ve aynı zamanda petrole ilişkin tesislerin kurulduğu ve sanayi sektöründe istihdamın yaratıldığı bir süreçtir. Kurulan bu tesisler sayesinde petrol ürünleri ticarete konu olmuş, yan sanayi ve diğer kuruluşlar bu süreci desteklemiştir. Kent bu dönemde yarattığ 1 istihdam sayesinde hızlı bir imar faaliyetine sahne olmuş ve kısmen de olsa bu imar, planlı gerçekleşmiştir (Alaeddinoğlu, 2010).

Batman, 1980'li yılların ortalarından itibaren ise çarpık kentleşme ve gecekondulaşma kültürünün egemen olmaya başladığı bir süreçle tanışmaya başlamıştır. TPAO'nun yaratmış olduğu istihdam ve çoğaltıcı etki hızla kaybolmaya başlarken, istihdam beklentisine dayalı hızlı nüfus artışı ve güvenlik kaygıları nedeniyle ortaya çıkan yeni bir göç dalgası, Batman'ın kentleşme sürecini bambaşka bir boyuta taşımıştır. Nitekim 1985-2000 yılları arasını kapsayan 15 yıllık süreçte kent nüfusu yaklaşık 2.5 kat artmıştır (Şekil 3). Batman'ın gerçek anlamda çarpık kentleşme süreci ile tanıştığ 1985-2000 y1lları aras1, aynı zamanda nitelikli arazilerin en yoğun şekilde yerleşmeye açıldığı bir süreci de beraberinde getirmiştir. Kentte 2000'li y1llardan sonra ise petrole bağlı sanayi fonksiyonu iyice gerileyerek, yerini hizmet fonksiyonu ve onun çoğaltıcı etkisine bırakmıştır. Hizmete dayalı kentsel fonksiyonların gelişmesine paralel olarak Batman kenti alansal olarak büyümeye devam etmiş ve çevresindeki tarım arazileri ile fundalık alanlar hizmet fonksiyonu amaçlı kullanımlar için istila edilmiştir.

Günümüzde Batman kenti 39 mahalleden oluşan büyük bir kent görünümündedir (Şekil 4). Özellikle kent, son 30 yılda geçirmiş olduğu çarpık kentleşme süreci ve yoğun göçler nedeniyle sosyal ve toplumsal alanda ciddi sorunlarla karşı karşıya kalmıştır. Bu sağlıksız ve plansız gelişim süreci sonucunda Batman modern kentleşme sürecini 


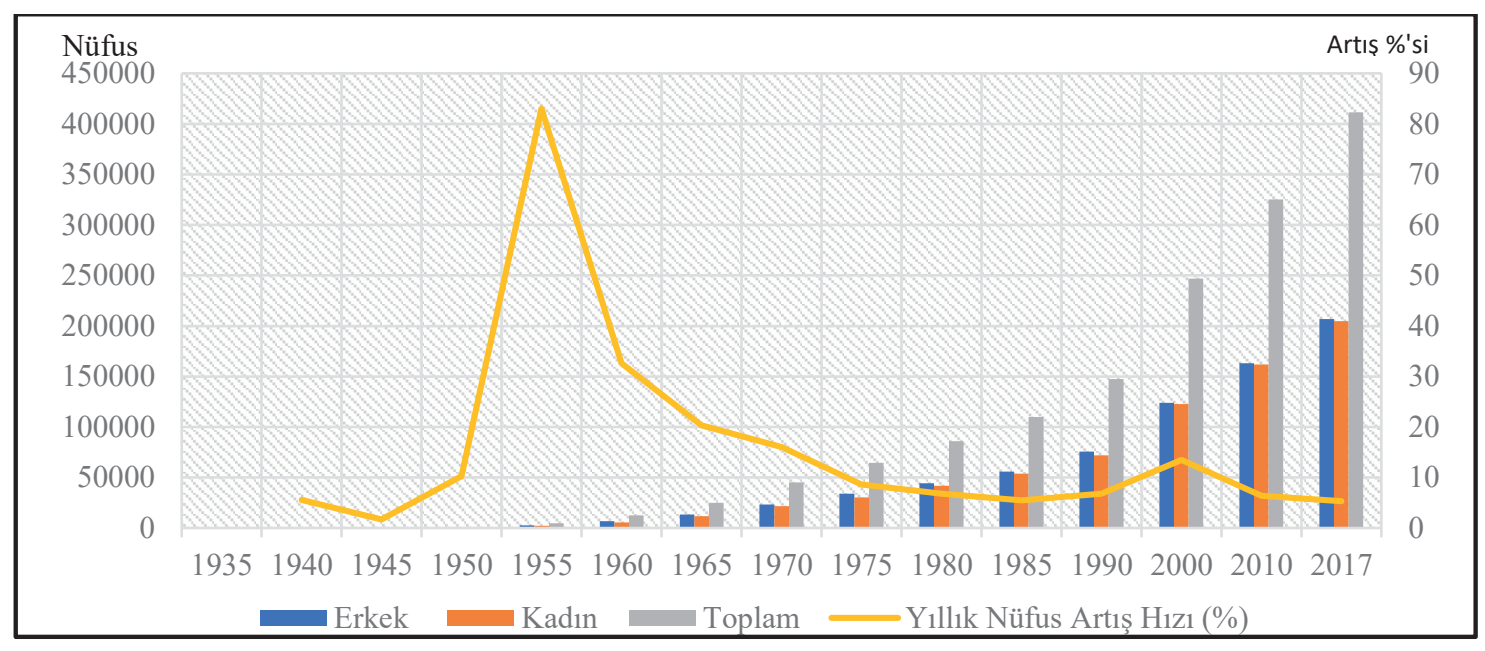

Şekil 3. Batman kentinin yıllara göre nüfus artış oranları (1935-2017)

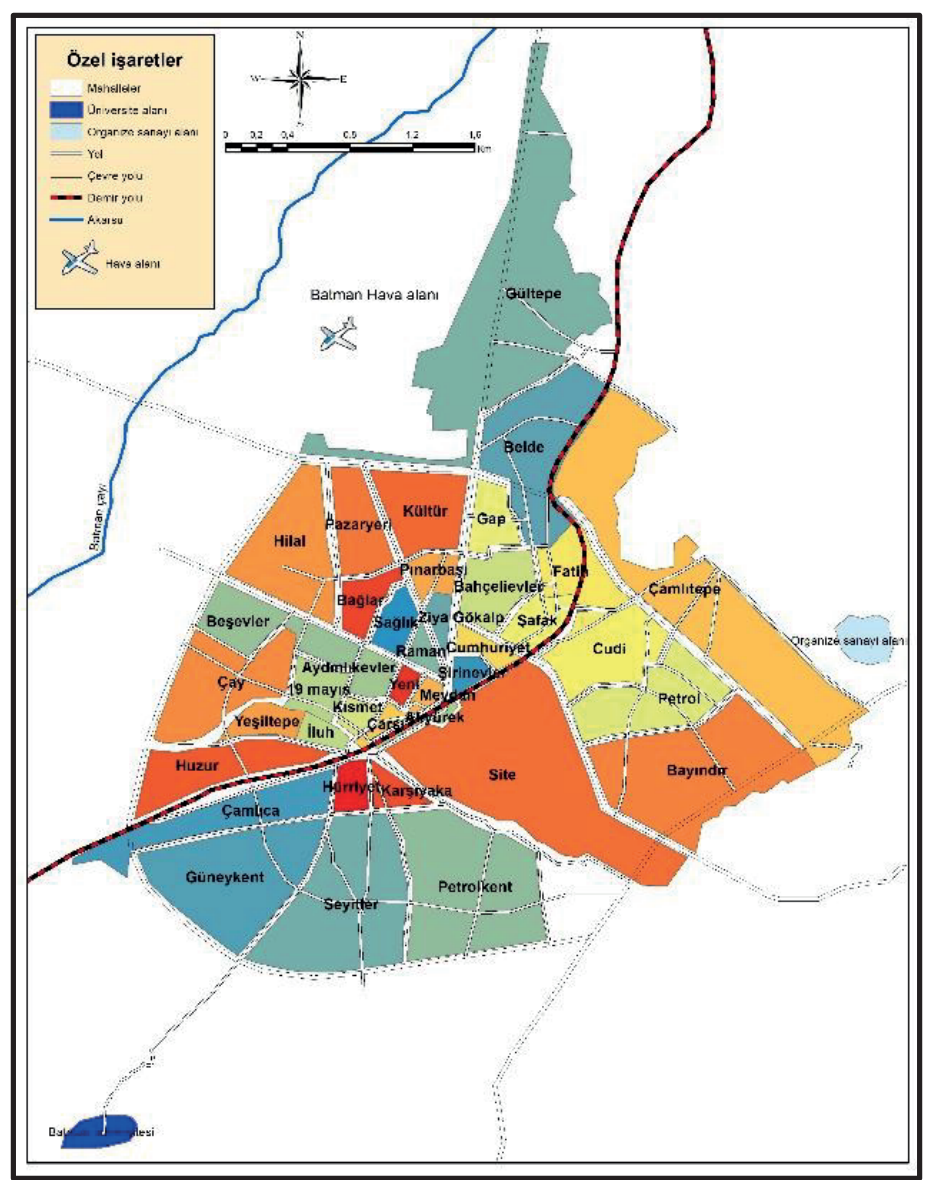

Şekil 4. Batman kentinde mahallelere göre yerleşim haritası

tamamlayamamıştır. Nüfus artışı ve göç baskısı devam ettiği için planlı kentleşme anlamında atılan adımlar da yetersiz kalmaktadır.

\subsection{Batman kentinde arazi sınıflarındaki değişimi izlemek için kullanılan yöntemler}

Bu çalışmada, UA ve CBS teknikleri ile uydu görüntüleri kullanılarak kentsel gelişim ve değişim belirlenmeye çalışılmıştır. Batman kentinin kentsel gelişimini ve arazi sınıflarındaki değişimi belirlemeyi amaçlayan bu çalışmanın iş akışı Şekil 5 'te gösterilmiştir.

Buna göre çalışmada, 30 metre mekânsal çözünürlükte 25.07.1985 ve 21.07.2016 tarihlerine ait Landsat TM ETM+ ve OLI/TIRS uydu görüntüleri kullanılmıştır (Anonymous, 2018). 


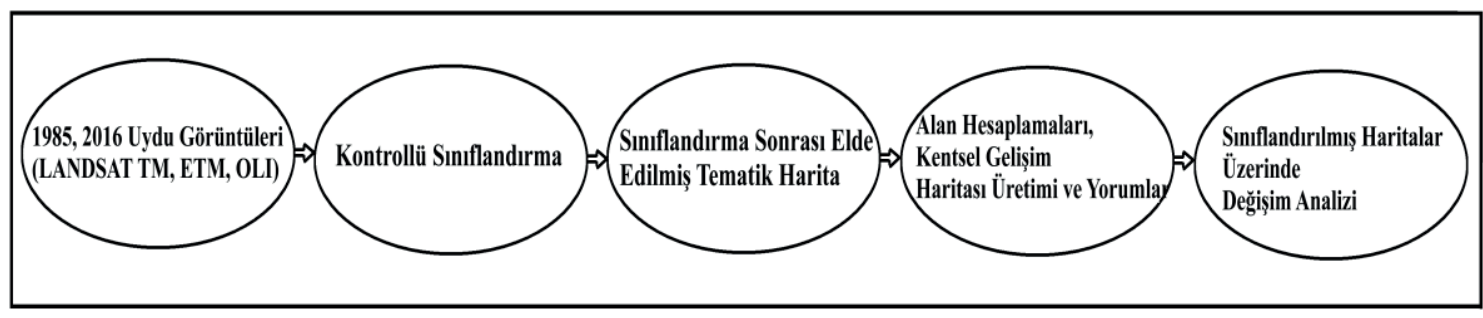

Şekil 5. Çalışma akış şeması

Erdas 2014 programiyla Landsat TM uydu görüntüleri Layer Stack yapılarak tek görüntü haline getirilmiştir. Kentsel alanların daha iyi belirlenmesi için 3-2-1 bant kombinasyonu elde edilmiştir. En Çok Benzerlik (Maximum Likelihood) sınıflandırma yöntemi uygulanarak kontrollü sınıflandırma yapılmıştır. Kontrollü sınıflama ile belirlenen arazi örtüsü alanları hektar olarak tespit edilmiştir. Burada kontrollü sınıflama yapılmasının amacı, arazi ile ilgili diğer dokümanlara ve arazi gözlem bilgilerine sahip olunduğu için görüntülerde alanlarla ilgili yanlışlıklar düzeltilmektir. Erdas 2014 programı kullanılarak Landsat TM uydu görüntüleriyle ortaya çıkarılan kentsel alanların sınırları, daha sonra ArcGIS10.5 programı kullanılarak çizilmiştir. Landsat MSS uydusunun 1985 yılına ait görüntüsü diğer Landsat TM uydu görüntüleriyle çakıştırılmıştır. Batman'ın 1985 ve 2016 uydu görüntülerinden hareketle kent ve çevresinde arazi kullanım şeklinde nasıl bir gelişme olduğu belirlenmiștir. Bunlara ek olarak 1985-2016 yılları arasındaki süreçte kentsel gelişim alanı içerisinde arazi kullanım kabiliyet sınıflamasına göre kentin hangi alanlar üzerinde ne kadar genişlediği ortaya konmuştur.

\section{Bulgular ve Tartışma}

3.1. Arazi kullanımı/örtüsü değişimlerinin zamana bağlı olarak belirlenmesi

Plansız kentleşmenin önüne geçmek, kentsel ve bölgesel gelişimi doğru planlamak, ekili-dikili arazi kullanım politikaları geliştirmek, konut, ticaret, ulaşım, eğitim, kamu servisleri, aktif ve pasif rekreasyon alanlarının uygun yerlere dağılımını sağlamak için arazi kullanımı örtüsünün güncel durumu ve zamansal değişimi hakkında bilgilere ihtiyaç vardır. Arazi kullanım örtüsündeki zamansal değişimler, ekonomik, sosyal, politik ve ekolojik şartların bir sonucudur ve bu değişimin yönü ve miktarı hakkında somut veriler gelecekteki nüfus artışın ve buna bağlı olarak kentsel yayılmanın yönünü ve gereksinimleri belirlemek açısından önemlidir (Öztürk ve ark., 2010). Bu bakımdan ele alındığında Batman kentinin çok kısa bir zaman aralığında arazi kullanımında çok büyük değişismler yaşadığı görülmektedir. Nitekim başlarda 10 hektara yakın küçük bir yerleşme iken, zamanla yerleşmeler hızla genişleyerek tarım arazileri ve bitki örtüsünü işgal ederek, yaklaşık 3000 hektarlık bir yüzeyi kaplamıştır. Bu arazi kullanım örtüsünün çok dikkatli bir şekilde izlenmesi gerektiğini ortaya koymaktadir.

Kentsel gelişim/yayılım alanının ve yönünün arazi kullanımına etkisini belirlemek iki açıdan büyük önem taşımaktadır. Birincisi; kentsel gelişimin/yayılımın olduğu alanlarda ekonomik potansiyel anlamında hangi alanlarda (tarım, otlak, ormanlık vb.) yoğunluk gösterdiğinin ortaya konulması büyük önem arz etmektedir. İkincisi ise, mevcut kentsel alanın kentsel gelişim/yayılımın olacağı alanların ekonomik potansiyeli yüksek olan alanlarda olmamasına dikkat edilmesi ayrı bir değer taşımaktadır. Bunlara dikkat edildiği takdirde, nüfus artış hızı ve dolayısıyla gelişecek kentsel gelişim/yayılım alanlarının verimli tarım alanlarını işgal edilmemesine özen gösterilmesi sağlanmış olacaktır. Daha da önemlisi bir bütünlük yaklaşımı içerisinde doğal ortam dengesi bozulmadan kentsel gelişim/yayılım yönü ve alanları belirlenerek planlanması gerçekleşmiş olacaktır (Benek ve Şahap, 2016). Bunun yanında tarım alanlarının amacı dışında kullanılmasının önlenebilmesi, kentsel saçaklanmanın tarımsal üretim alanlarına doğru yayılmasının önüne geçilebilmesi, arazilerin yetenek sınıflarına göre kullanılmasının sağlanması toplumun refah seviyesinin yükseltilmesi ve gelecek nesillerin tarımsal faaliyetleri sürdürebilmesi adına oldukça önemlidir (Uzun ve Demir, 2016). Ancak belirtilen hususlara göre Batman kenti değerlendirildiğinde, günümüze kadar kentsel gelişim alanları ve doğrultularının oldukça özensiz seçildiği ve bir plan dâhilinde gerçekleşmediği açıkça görülmektedir. Bu durum zaman içerisinde ciddi arazi kullanım hatalarının ortaya çıkmasına ve önemli ekonomik kayıpların yaşanmasına yol açmıştır.

\subsubsection{Batman kentinin $1955-1985$ yılları arasındaki arazi kullanımı değişimi}

İluh köyünün Batman kentine dönüşüm sürecinin yaşandığ 1950 'li yılların ikinci yarısında, kentte mekânsal gelişim tamamen demiryolu ile TPAO’nun tesisleri etrafinda gelişmiştir. $\mathrm{Bu}$ 
dönemde oldukça küçük bir alan kaplayan yerleşmenin etrafinda geniş tarım arazileri ile fundalık, yer yer ağaç kümeleri ve step bitkilerinden oluşan geniş bir arazi bulunmaktaydı. Kent 1950'li yılların sonunda kurulan TPAO tesisler sayesinde petrol ürünleri ticarete konu olmuş ve yan sanayi ile diğer kuruluşlar bu süreci desteklemiştir. Kent bu dönemde yarattığı istihdam sayesinde hızlı bir imar faaliyetine girmiş ve kısmen de olsa bu imar, planlı gerçekleşmiştir. Bu dönemde Batman İluh Mahallesi ile doğuya doğru TPAO arasındaki alan içerisinde gelişmiştir. İlk olarak kent İluh Mahallesi'nden doğuya doğru Çarşı Mahallesi'ne doğru büyümüştür. Daha sonra Kısmet ve Aydınlıkevler mahalleleri kurularak TPAO'ya kadar olan alan gelişmiştir. Kentsel gelişim 1960'lı yılların başında doğuya doğru genişlemeye devam etmiş olup, bu yıllarda TPAO çalışanları için yapılan Site Mahallesi, planlı yapılaşmanın en güzel örneğini oluşturmaktadır. Kentin ilk gelişen mahalleleri konumunda olan Çarş1, Kısmet, Aydınlıkevler, Site, Yeni, Meydan ve Akyürek gibi mahallelerde, nispeten planlı ve gelişmiş ülkelerin kentsel gelişimine benzer bir büyüme gerçekleşmiştir. Nitekim geniş caddeler, yollar ve meydanların varlığı bunun en güzel örneğidir.

Kentte modern rafinerinin 1966 yllinda kurulması ve buna bağlı üretim artış1 sonucunda çok hızlı bir işçi göçü yaşanmasına yol açmıştır. Bu dönemde kent her yıl binlerce göç almış ve etrafindaki arazilere doğru çok hızlı bir şekilde yayılmıştır. Nitekim başlangıçta kent doğuya doğru yayılırken, 1970'lerin başında ise kuzeye açılmaya başlamıştır. Bu yıllarda iş ve ticaret merkezleri kuzeyde demiryolu boyunca gelişmiş ve Raman, 19 Mayıs, Beşevler ve Şirinevler gibi mahalleler ortaya çıkmıştır. Yeni kurulan iş ve ticaret merkezlerinin çevresinde ise yoğun bir şekilde meskenler yapılmaya başlanmıştır. Başlangıçta doğudaki planlı gelişim karakteri kuzey gelişim yönünde kaybolmaya başlamış ve yerini sıkışık ve plansız bir yapılaşmaya bırakmıştır. Artan nüfus baskısı ve planlama esaslarına bağlılık ilkesine uyulmaması gibi hususlar, Batman kentinde 1970'li yılların sonuna doğru plansız bir kentleşme sürecinin başlangıcını beraberinde getirmiştir. $\mathrm{Bu}$ yıllarda kentsel gelişim kuzey ve kuzeydoğu doğrultuda gelişmeye devam etmiş ve Sağlık, Ziya Gökalp ve Cumhuriyet gibi yeni mahalleler kurulmuştur. Bu dönemde kurulan mahallelerin çoğunda planlı bir kentleşmeyi görmek mümkün değildir. Zira yoğun göç hareketi, bu mahallelerin çarpık bir şekilde gelişmesine neden olmuştur.

Kentleşme sürecinin başladığı 1950'li yıllardan 1980'li yılların başına kadar Batman'da 15 mahalle kurulmuştur. Kentsel gelişim yönü söz konusu dönemde önce doğu sonra kuzeye doğru gerçekleşmiştir. $\mathrm{Bu}$ dönemde TPAO'nun itici etkisiyle ekonomik, sosyal ve kültürel anlamda büyük bir dönüşüm gerçekleşmiştir. Petrole dayalı sanayinin yarattığı istihdam ve buna bağlı olarak gelişen ekonomik ve kültürel gelişim, mekânsal gelişimi de etkilemiştir. Ancak 1980'li yılların başından itibaren yoğun nüfus baskısı ve hızlı nüfus artışı, sanayiye dayalı kentsel gelişimin etkisini yitirmesine ve beraberinde önemli ekonomik, sosyal ve mekânsal sorunların ortaya çıkmasına yol açmıştır. 1980'li yıllardan önce kent kaynakları hızlı nüfus artışı ve göçler karşısında nispeten yeterli gelirken, 1980'li yıllardan sonra ise göç baş edilemez noktaya gelmiş ve önemli sorunlar yaratmaya başlamıştır. Özellikle arazi kullanımı ve buna bağlı olarak tarım arazilerinin kent birimleri tarafindan istila edilmesi ve hızla alan kaybetmesi bu dönemle birlikte oldukça hızlanmıştır. Batman kenti 1985 y1lına gelindiğinde 110036 nüfusa sahip büyük bir kente dönüşürken, mahalle sayısı ise 20’yi aşmıştır. Kent 1955 yılında yaklaşık 10 hektarlık bir alana yayılmışken, 1985 yılına gelindiğinde kentsel alan 1033 hektar olup, 30 y1llık periyotta 100 kat kadar bir alansal büyüme gerçekleşmiştir.

\subsubsection{Batman kentinin 1985-2016 yılları arasındaki arazi kullanımı değişimi}

Batman kentinde petrol çıkarımı ve TPAO tesislerinin kurulmasıyla başlayan kentleşme serüveni, 1985 y1lından itibaren bambaşka bir yöne doğru gitmiştir. Zira başlarda TPAO'nun yarattığ istihdam ve buna bağlı olarak gelişen iş ve ticari faaliyetler, önemli bir kentsel çekicim gücü olarak nüfusun kente yönelmesine neden olmuştu. Ancak 1985 yılında itibaren petrol sanayisinin ürettiği istihdam potansiyeli yok olmaya başlamasına rağmen, kent önceki yıllara göre çok daha fazla göç almaya ve mekânsal olarak çok daha hızlı büyümeye devam etmiştir. Özellikle çevre illerden istihdam beklentisi ile kente yönelen nüfus ile terör olaylarından dolayı çevredeki kırsal yerleşmelerden gelenler büyük bir göç dalgası yaratmış ve kent nüfusuna her yıl onbinlerce kişi dâhil olmuştur. Söz konusu nüfus akını Batman'da sürdürülebilir olmaktan çıkmış ve birçok soruna yol açarak, kentsel kaos olarak adlandirılabilecek bir olguyu ortaya çıkarmıştır (Alaeddinoğlu, 2010).

Batman kent nüfusu 1985 y1lında 110036 iken, 2016 y1lında 411251 'e yükselmiştir. Otuz yıllık bu süreçte kent nüfusu yaklaşık 4 kat artmıştır. $\mathrm{Bu}$ dönemde Batman eski mahallelerin çevresinde büyümeye devam ederken, güneyde ve batıda da yeni mahalleler ortaya çıkmıştır. Kentteki yatay gelişmenin yönü bir önceki döneme benzemekle beraber, alansal büyüme bakımından oldukça farklı bir özellik gösterir. Zira bu dönemde kuzeyde 
kurulan GAP, Kültür, Belde, Pınarbaşı, Pazaryeri gibi mahalleler planlı ve çok katlı binalardan oluşurken, Erköklü, Çay, Hilal gibi mahalleler gecekondulaşma alanı olarak ortaya çıkmışlardır. Ancak asıl gecekondulaşma alanları ise güneydeki Huzur, Seyitler, Çamlıca Petrolkent, Yesiltepe, Çamlıca gibi mahalleler olmuştur. 1990'dan sonra bu şekilde gecekondu mahallelerinin kurulması bu dönemde kırsaldan çok fazla göç aldığını göstermektedir. $\mathrm{Bu}$ son göç dalgasıyla birlikte kentin İluh Deresi güneyinde kalan bölümü tamamen gecekondu bölgesi olmuştur. Gecekondu mahallelerinin artışıyla birlikte Batman'da önemli sosyal ve ekonomik sorunlar yaşanmaya başlanmıştır.

Kentte cadde sokak sistemleri, altyap1 ve üstyap1 noktasında planlı büyüme Gap, Kültür, Pınarbası, Bahçelievler mahallelerini yeni cazibe merkezleri haline getirmiştir. Eski mahallelerdeki çarpık yapılaşma, yeni iş ve ticaret alanlarının bu yeni sahalara kaymasına neden olmuştur. Ancak planlı gelişen mahallelerin dışında kentin batı ve güneydeki kenar semtleri özellikle terör nedeniyle kırdan göçle gelenlerin akınına uğramıştır. Bu dönemde Batman Güneydoğu Anadolu Bölgesi'ndeki birçok il gibi, 1990 yılından sonra çevresindeki kırsal alanlardan büyük oranda göç almıştır. Güvenlik sorunlarından kaynaklanan bu göçler, ülke gelişmişlik sıralamasının diplerinde yer alan şehri adeta boğmuştur. Sosyo-ekonomik gelişmişlik göstergeleri bakımından zaten ülkenin geri kalmış bölgesi olan Batman, bir de zorunlu olarak yeni gelenlerin de sorunları da eklenince, deyim yerindeyse, nefesi kesilen bir kente dönüşmüştür (Alaeddinoğlu, 2010). Şüphesiz bu durum özellikle kenar mahallelerde arazi üzerinde önemli bir baskıya ve gecekondulaşmaya neden olmuştur. Böylece kentin çevresinde yer alan tarım arazileri bu plansız ve yoğun göçler nedeniyle hızla dönüşerek, yerleşmeye açılmıştır.

Günümüzde Batman kenti çevresindeki tarım arazilerine doğru gelişimini hızlı bir şekilde sürdürmeyi devam etmektedir. Sanayi fonksiyonu ve onun çoğaltıcı etkisine dayalı olarak ortaya çıkan kent, bugün artık bir hizmet kentine dönüşmüştür. Kent, önceki dönemler kadar olmasa da göç almaya devam etmekte ve gelişen hizmet fonksiyonun ihtiyaçlarına yönelik arazi ihtiyacını sürekli olarak çevresindeki tarım arazileri ile otlak ve mera vasfındaki arazilerden karşılamaktadır. $\mathrm{Bu}$ durum nitelikli tarım arazilerinin yok olmasına ve önemli arazi sorunlarının ortaya çıkmasına yol açmaktadır. Batman, özellikle kuzey, güneybatı ve batı kısmında çok daha hızlı genişlemekte ve eğitim, konut, iş ve ticaret alanları için bu sahalardaki verimli araziler yok olmaktadır.

\subsection{Batman'da 1985-2016 yılı arazi kullanımı ve Landsat uydu görüntüsü arazi değişimi}

Batman kenti ve yakın çevresinin 1985 ile 2016 yıllarındaki arazi kullanım yapısı incelendiğinde, önemli değişimlerin ortaya çıktığı açıkça görülmektedir. Buna göre 1985 yılındaki Landsat45 uydu görüntüsünden elde edilerek yapılan arazi dağılışı haritası incelendiğinde, Batman kenti ve yakın çevresini kaplayan yaklaşık 20000 hektarlık arazinin varlığından bahsedilebilir. Söz konusu arazinin yaklaşık \% 70'i (13653 ha) kuru tarım alanlarından oluşurken, \% 10.7'si (2078 ha) sulu tarım arazileri, \% 10.3'ü (2016 ha) ise otlak ve meralardan oluşmuştur (Tablo 2). Batman'da 1985 yılındaki arazi kullanımında yerleşmeler ve kentsel alanı miktarı ise 1033 hektar kadar olup, mevcut arazinin \% 5.3'ünü oluşturmak idi. Yeşil alanlar ile çıplak sahaların kapladığ 1 alan da 693 hektar olup, toplam arazinin yalnızca \% 4'ünü meydana getirmekteydi (Şekil 6). Dolayısıyla 1985 yılında Batman kenti ve yakın çevresindeki arazinin büyük bir kısmı kuru ve sulu tarım arazilerinden oluştuğu görülmektedir.

Diğer yandan Batman kentinin kapladiğ 1985 yılında 1033 hektar olmasına rağmen önceki yıllarla kıyaslandığında çok büyük bir alansal genişleme gerçekleştirdiği görülmektedir. Nitekim 1955 yılında kentin çekirdeğini oluşturan İluh Mahallesi, 10 hektardan daha küçük bir alan kaplamaktaydı. Ancak zaman içerisinde çok hızlı bir şekilde yerleşme etrafına doğru genişleyerek, çevresindeki sulu ve kuru tarım arazilerini işgal etmiştir. Kent 1955-1985 yılları arasını kapsayan dönemde y1llık ortalama 30 hektarlık bir alansal büyüme gerçekleştirmiştir. $\mathrm{Bu}$ dönemde Batman Diyarbakır, Siirt ve Bitlis gibi komşu illere doğru demiryolu ve karayolu doğrultuları boyunca kuzey ve doğuya doğru genişlemiştir.

Tablo 2. Batman kenti ve yakın çevresinin 1985 ile 2016 yıllarındaki arazi örtüsü durumu

\begin{tabular}{lcccc}
\hline & 1985 (hektar) & $\%$ & $2016($ hektar) & \% \\
\hline Yerleşme & 1033 & 5.3 & 2763 & 14.3 \\
Sulu tarım & 2078 & 10.7 & 3278 & 16.9 \\
Çayır/mera & 2016 & 10.3 & 1100 & 5.6 \\
Yeşil alan & 267 & 1.4 & 566 & 2.9 \\
Çıplak alan & 426 & 2.2 & 516 & 2.6 \\
Kuru tarım & 13653 & 70.1 & 11250 & 57.7 \\
\hline Toplam & 19473 & 100 & 19473 & 100 \\
\hline
\end{tabular}




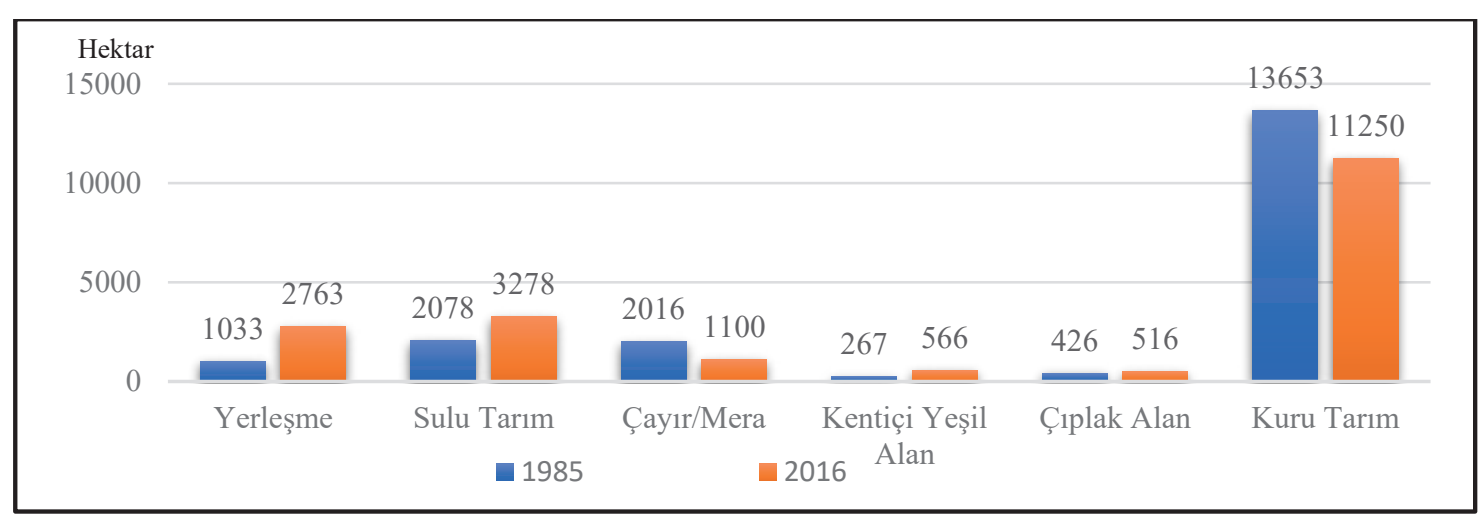

Şekil 6. Çalışma sahasında arazi kullanımının 1985-2016 yılları arasında alansal değişimi

Batman kenti ve yakın çevresinin 2016 yılı Landsat 8 OLI uydu görüntüsü neticesinde oluşturulan arazi kullanım haritası incelendiğinde, 1985 yılındaki arazi kullanımına göre oldukça önemli değişimlerin ortaya çıktığı görülmektedir (Şekil 7). Buna göre kent ve yakın çevresindeki arazilerin önemli bir kısmının niteliksel olarak değiştiği ve kentsel kullanıma sahne olduğu anlaşılmaktadır. Batman kenti ve yakın çevresinin 2016 yılı arazi kullanımı ele alındığında kuru tarım arazisi 11250 hektarlık bir alana sahipken, sulu tarım arazisi 3278 hektar, çayır/mera 1100 hektar, yeşil alan 566 hektar, çıplak alanlar 516 hektar, yerleşme ve kentsel alanlar ise 2763 hektarlık bir alan kaplamaktadır (Şekil 8). Buna göre inceleme alanında 1985 yılı ile mukayese edildiğinde 2016 yılında kuru tarım arazisi ile otlak/mera arazileri önemli oranda azalırken, yerleşme alanları ve kentsel alan yaklaşık 3 kat büyümüştür. Tarımsal tekniklerin gelişmesi ve sulama imkânlarının artmasıyla birlikte sulu tarim arazilerinin de nispeten arttığı görülmektedir.

Landsat 8 OLI uydu görüntüsü verileri incelendiğinde, Batman kentinin son 30 yılda yaklaşık 1700 hektarlık bir alansal büyüme gerçekleştirmiştir. Kent 1985 yılından 2016 yılına kadar yıllık ortalama 60 hektarlık bir büyüme sağlamıştır. Bu süreçte yıllık bazda ortalama \% 6 civarında bir alansal büyüme gerçekleşmiştir. Kuşkusuz bu büyüme eğiliminde göçlerin büyük bir etkisi söz konusuyken, göçlerin yanı sıra Batman'ın bu süreçte gelişmiş bir hizmet kentine dönüşmesinin de büyük bir etkisi vardır. Kentte sağlık, eğitim, ticaret, ulaşım ve askeri alandaki yatırımların artması ve söz konusu fonksiyonlar için günümüz koşullarına uygun yeni kentsel arazi ihtiyacı ortaya çıkmıştır. Mevcut kentsel alanda söz konusu ihtiyacı karşılayacak yeterli ve uygun kent içi arazi olmadığından, söz konusu hizmet fonksiyonlarının arazi talepleri daha çok kentin saçaklarındaki tarım arazileri ile otlak ve mera arazilerinden karşılanmaktadır.
Bilindiği üzere ülkemizde 1990’lı y1llarla birlikte ulaşım, iletişim ve haberleşme sektörlerinde meydana gelen değişimler, kentlerin büyümesini etkilemiştir. $\mathrm{Bu}$ değişimler doğrultusunda kent merkezindeki büyüme, sıçrayarak otoyol kavşak ve aktarma noktalarında gelişen merkez ve otoyolları birbirine bağlayan ana bulvarlar üzerinde doğrusal gelişen merkez şeklinde gerçekleşmiştir (Akın, 2012). Sanayi birimlerinin her 10 yilda bir kentin bir diş çemberi yönünde hareket ettiği ve boşalan sanayi alanlarının fonksiyon değiştirerek kent merkezi işlevlerine konu olduğu görülmektedir. Üretim ilişkileri ve hizmetler sektörünün yeniden düzenlenmesi, üretim, iletişim teknolojilerinin değişmesi farklı gelir grupları arasındaki dengesizlikleri arttırmıștır. Bu doğrultuda yeni gelir gruplarının yaşam anlayışları, mekânsal ihtiyaçları ve beklentileri de değişmiştir. $\mathrm{Bu}$ değişimin yansıması olarak yeni konut alanları, eğlence ve rekreasyon alanları mevcut kentten ayrışarak farklı alanlarda yer seçmeye başlamış, değişen sanayi ölçeği ve alt sektörler bazında uzmanlaşmanın mekânsal yer seçim kriterlerinin de farklılaşmasıyla kent makroformu biçimlenmeye devam etmiştir. $\mathrm{Bu}$ doğrultuda bu sektörlerin taleplerine uygun arazilerde çevreye ve sıkışık kent merkezinden uzakta yer almıştır. Söz konusu durum aynı şekilde kent çevresindeki tarım arazilerinin kentsel kullanımlar lehine dönüştürülmesine neden olmuştur.

Öte yandan Türkiye'de 2000 y1lı sonrasında kamu ve özel sektör yatırımlarının büyük ölçüde inşaat sektörüne yönlendirilmesi, başta konut olmak üzere, alışveriş merkezi, plaza, özel eğitim ve sağlık yapıları ile ulaşım altyapısı üretimini arttırmış ve böylece kentsel mekânın şekillenmesinde bu yapılar belirleyici olmuştur (Seydanlığlu ve Turgut, 2017). Aynı durum Batman kenti içinde geçerli olmuş ve 2000'li y1llarla birlikte Batman kentinin mekânsal gelişiminde orta ve üst gelir grubunun taleplerine uygun konut alanları, eğitim, sağlık ve sanayi yatırımları belirleyici olmuştur. Ayrıca 


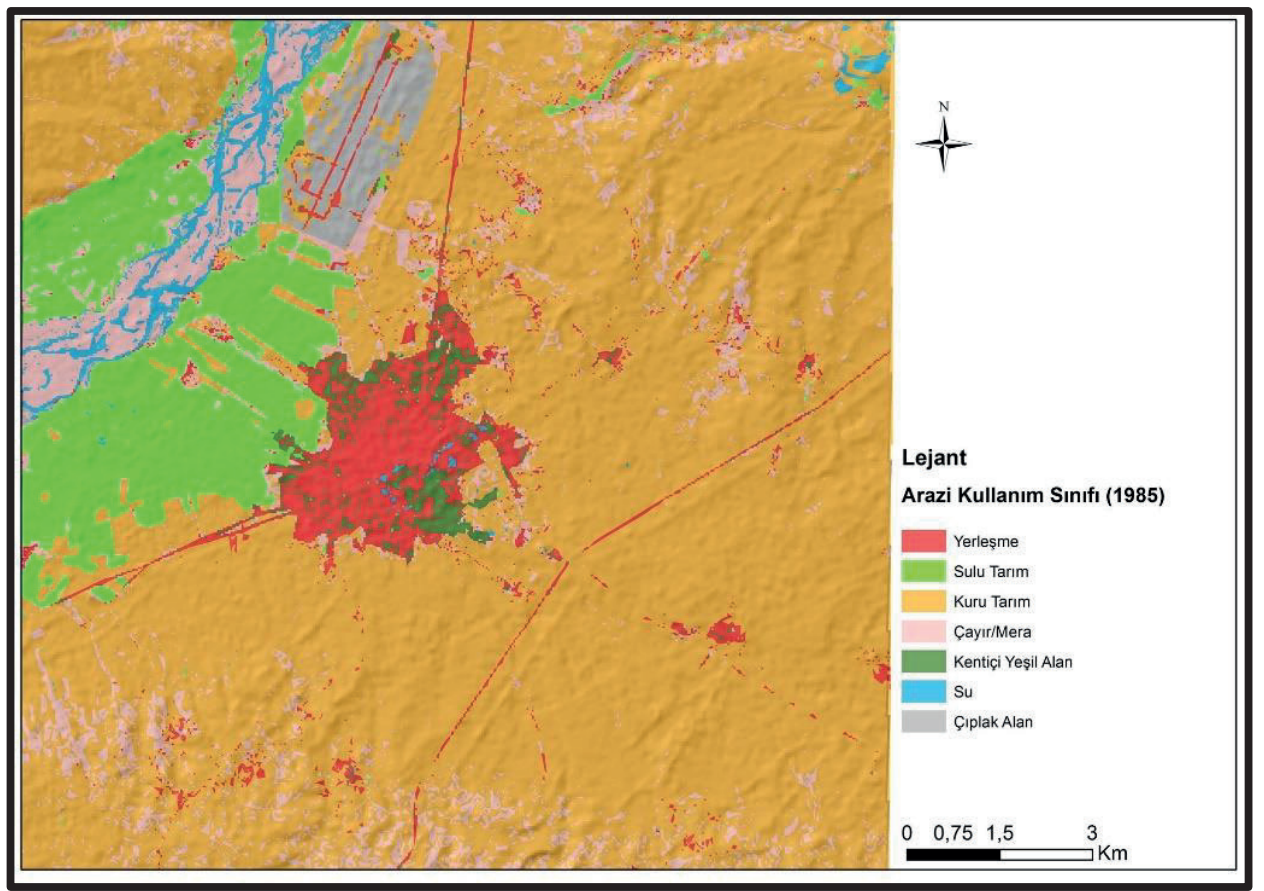

Şekil 7. Çalışma sahasının 1985 yılı arazi kullanım haritası

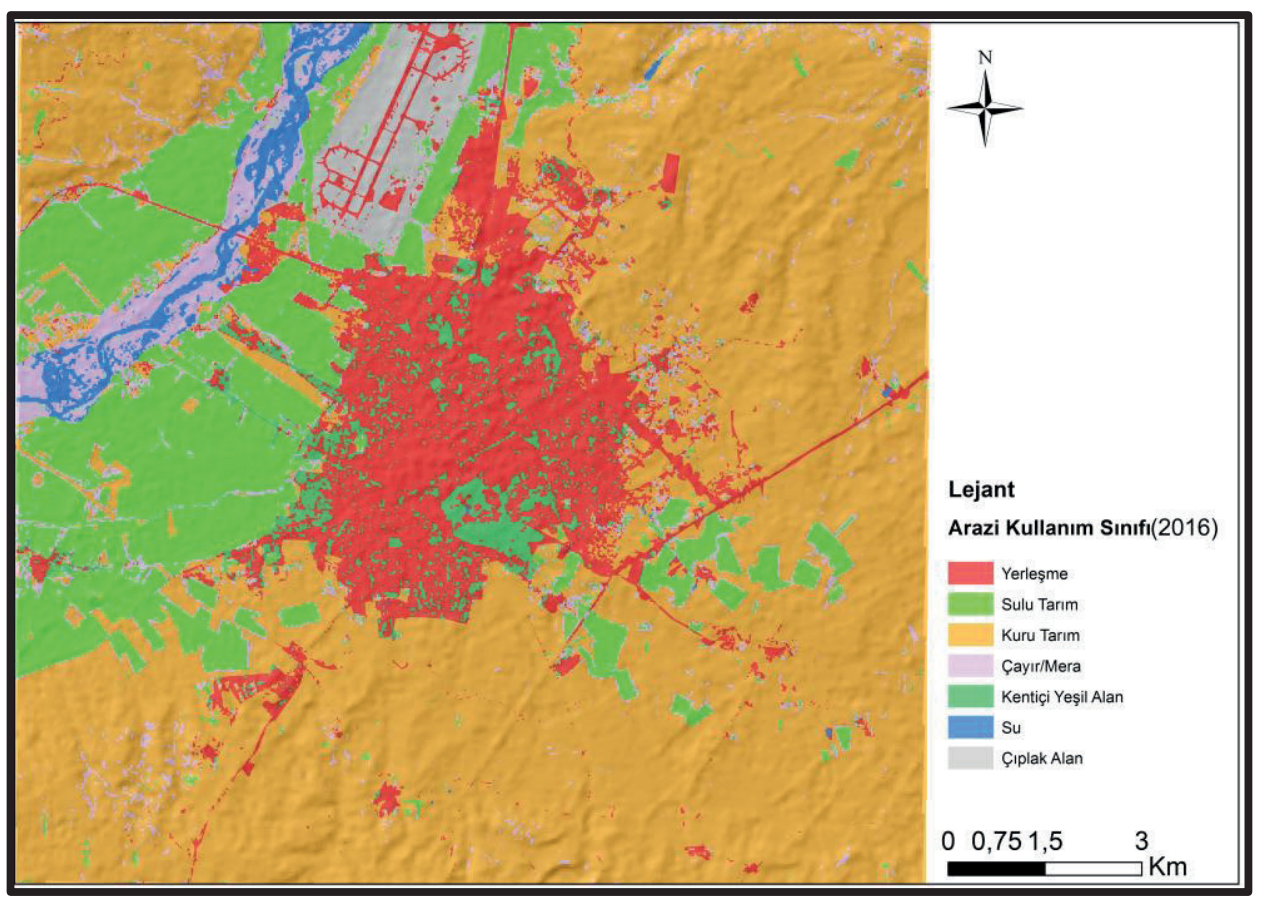

Şekil 8. Çalışma sahasının 2016 yılı arazi kullanım haritası

kentin makroformunun şekillenmesi, yeni konut alanlarının oluşturulması, kent merkezlerinin ve kent merkezindeki fonksiyonların revize edilmesinde ve dönüșümünde ulaşım ağları da belirleyici rol oynamıştır.

Batman kentinin 1985-2016 döneminde hangi yöne doğru alansal olarak büyüdüğüne bakıldığında, önceki gelişim yönü olan doğu ve kuzeye gelişimi devam ederken, son y1llarda ise daha çok güneybatıya doğru hızlı bir genişleme eğiliminde olduğu açıkça görülmektedir. Daha öncede belirtildiği gibi kentsel gelișimin doğrultusunu yeni konut projeleri, alışveriş merkezleri, sağlık kuruluşları, eğitim kampüsleri ile sanayi bölgeleri tayin etmektedir. Özellikle kentin kuzeydoğu-güneybatı aksı en hılı gelişen 
doğrultuları olup, bu doğrultu kente yeni bir makroform kazandırmıştır. Özellikle kuzey doğrultusu kentin bugüne kadar en fazla gelişen ve mekânsal büyümenin en çok gerçekleştiği yönü oluşturmaktadır. Diyarbakır ve Bitlis karayollarının uzandığ1 bu yönde, Batman Havaalanı da yer almaktadır. Her ne kadar havaalanı kentsel gelişmeyi kesintiye uğratsa da özellikle havaalanının doğu ve güneyi çok hızlı bir şekilde konut alanları, Toplu Konut İdaresi (TOKI) projeleri, alışveriş merkezleri, iş ve ticaret alanları ile sanayi siteleri gibi kentsel kullanışlara sahne olmuştur. Ayrıca Batman Bölge Eğitim Araştırma Hastanesi de kentin kuzeyine konumlanmış önemli bir kentsel çekim merkezi olarak dikkat çekmektedir. Hastane çevresinde gelişen iş ve konut alanları, bu yöndeki gelişime önemli bir katk1 sunmuştur. Bunun yanında kuzey kesimde Batman Havaalanı'nın hemen doğusunda sanayi sitesi yer almakta olup, kentsel gelişim yönünün kuzeye doğru uzanmasında önemli bir etkide bulunmaktadır.

Batman kentinin en önemli ikinci gelişim doğrultusu ise doğu yönündedir. Özellikle Siirt karayolu boyunca çok sayıda konut ve ticaret alanı doğuya doğru yayılmıştır. Ahmet Necdet Sezer Bulvarı boyunca iş ve konut alanları yoğun bir yayılış göstermektedir. Yerleşmeye elverişli düz arazilerin çokluğu, bu kesimde kentsel gelişimin yönü üzerinde belirleyici olmuştur. Mekânsal gelişimin doğuya doğru genişlemesinde etkili olan bir başka unsur ise Batman Organize Sanayi Bölgesi (BOSB)'dir. BOSB, 1991 yılında yatırım programına alınıp, 2002 yılında açılışı yapılmıştır. Yaklaşık 1640 dönümlük bir arazi üzerinde bulunan BOSB, Batman-Siirt Karayolu'nun kenarında kurulmuştur. Günümüzde 4000 dönümlük bir alanda hizmet veren BOSB, tarım arazisi vasfinda önemli bir araziyi işgal ederek, kentsel kullanıma dönüştürmüştür. Kentin doğuya doğru gelişimini sürdürmesinde BOSB'nin önemli bir etkisi vardır.

Batman'da kuzey ve doğudaki hızlı mekânsal gelişime kıyasla batı ve güney kentsel gelişim daha geç dönemde gerçekleşmiştir. Özellikle kuzey ve doğudaki kentsel gelişim sınırına erişilmesi, bu doğrultudaki gelişmeyi yavaşlatırken, yeni mekânsal gelişim doğrultusu olarak kentin güneybatısı ile batısı seçilmiştir. Bilindiği üzere üniversite kampüsleri, son y1llarda ülkemizde kentlerinde kentsel gelişimin doğrultusu ve arazi kullanımı üzerinde köklü değişimler gerçekleştirmiştir. Üniversite kampüslerine doğru konut ve iş merkezleri yoğunlaşmaktadır. Batman
Üniversitesi'nin yeni kampüs alanı olarak da kentin güneybatısındaki araziler belirlenmiş ve Batı Raman Kampüsü, kentin güneybatısına kurulmuştur. Dolayısıyla bu doğrultu kentin yeni gelişim yönü olarak dikkat çekmektedir. Gerek kampüs alanı gerekse çevresinde konut ve ticaret sahaları, önemli tarım arazilerinin istila edilerek, yerleşmeye açılmasına yol açmıştır. Kentin güneybatı doğrultusunda gelişiminde belirleyici olan bir başka faktör de Güneydeki Kuyubaşı mevkiinde inşa edilen TOKİ konutlarıdır. Yaklaşık 2000 konutluk bir proje gerçekleştiren TOKİ, bu mevkide yeni yaşam alanları ile iş ve ticaret sahaları oluşturmuştur.

Günümüzde Batman kentinin hızla büyümeye devam etmesi, göç olgusunun arazi kullanımı üzerinde sürekli bir baskı unsuru olması, kentte birçok doğrultuda mekânsal gelişim sınırına ulaşılmasına yol açmıştır. Özellikle son yıllarda kuzey, doğu ve güney kesimlerdeki kentsel fonksiyonlara uygun arazilerin oldukça azalması, kentsel kullanım talepleri için yerleşmeye ve yapılaşmaya çok uygun olmayan batı yöndeki Batman Çayı vadisine doğru uzanan sulu ve kuru tarım arazilerinin yerleşmeye sahne olmasına yol açmıştır. Özellikle İkiztepe köyü civarı ile Diyarbakır Karayolu çevresi, hızla yapılaşmaya maruz kalan sahalar olarak ortaya çıkmaktadır. Kentin gelecekte bu doğrultuda genişlemesini devam ettireceği öngörülmektedir. Nitekim Batman Şehirler Arası Otobüs Terminali ile birçok konut projesi bu doğrultuda yer almaktadır.

Öte yandan inceleme alanında 1985-2016 y1lı arazi kullanım sınıflarındaki oransal değişim grafiği incelendiğinde, yerleşme ve kentsel alanın neredeyse 3 kat arttığı görülmektedir. Buna göre 1985 yilında 1033 hektar olan kentsel alan, 2016 yılında 2763 hektara çıkmıştır. Kentsel alan 1730 hektarlık bir büyüme sağlamıştır. Kentsel alana ve yerleşmeye dönüşen arazinin \% 42.9'u (740 ha) kuru tarım arazilerinden oluşurken, \% 34.1'i (590 ha) çayır/mera arazisi, \% 17.3'ü (299 ha) sulu tarım arazisi ve \% 5.2'si (90 ha) ise yeşil alan arazilerinden oluşmaktadır (Şekil 9). Buna göre 1985-2016 dönemi arasında kentsel kullanıma açılan arazinin \% 90'a yakını kuru-sulu tarım arazisi ile mera arazilerinden oluşmaktadır (Şekil 10). Dolayısıyla Batman kenti 1985-2016 devresinde bir yandan çok hızlı bir şekilde mekânsal büyüme gerçekleştirirken, öte yandan bu büyüme tarim arazileri ile otlak/mera arazileri üzerinde gerçekleşmiş ve ekonomik değeri yüksek olan arazilerin kaybolmasına yol açmıştır. 


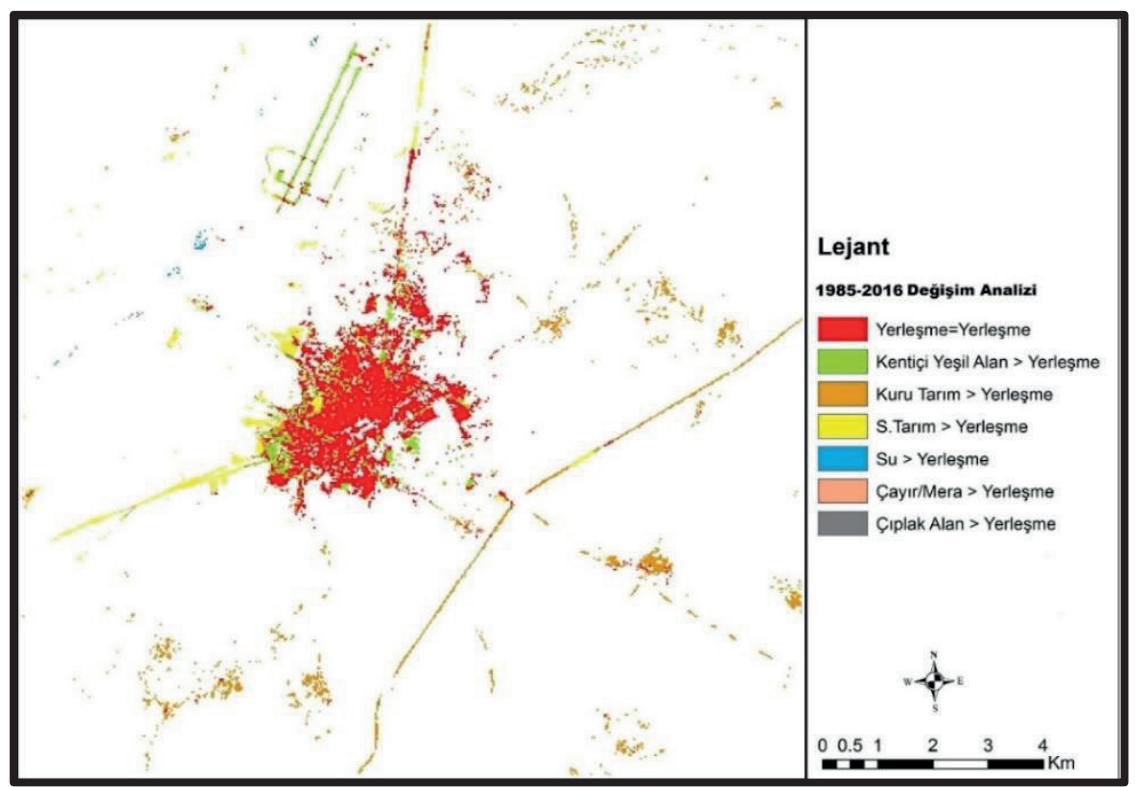

Şekil 9. Çalışma sahasında 1985-2016 yılları arasında arazi örtüsü değişim haritası

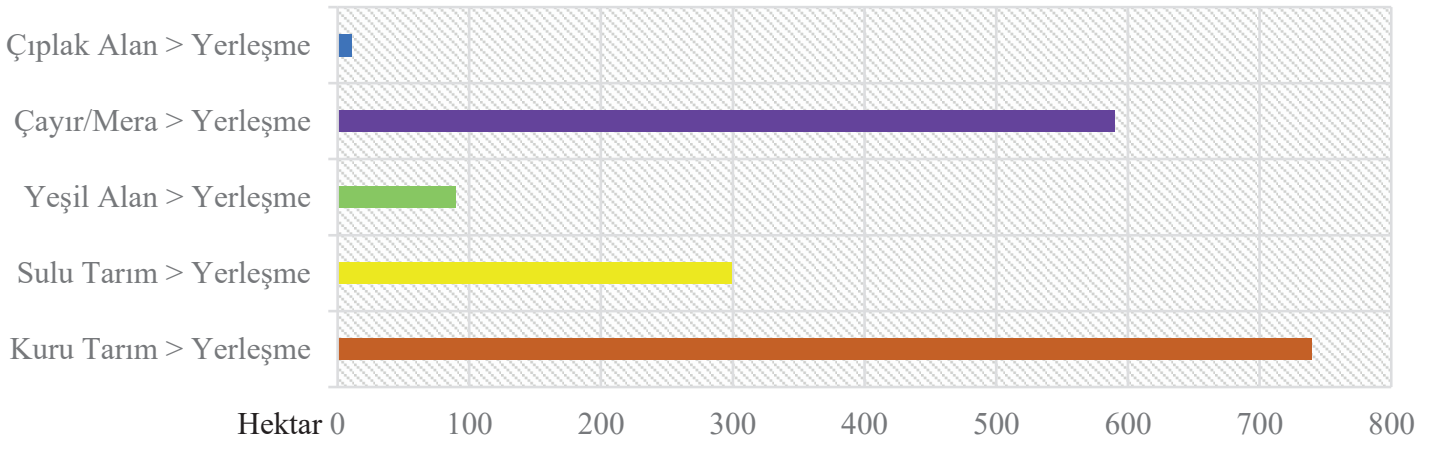

Şekil 10. Çalışma sahasında 1985-2016 arasında yerleşme alanlarına dönüşen arazi sınıfları miktarı

\section{Sonuçlar}

Batman, Türkiye'de hızlı kentleşme ve göç olgusunun olumsuzluklarıyla en fazla boğuşan kentlerden biri olmuştur. Petrol sanayisinin ortaya çıkmasıyla küçük bir köyden büyük bir kente dönüşen Batman, başlarda sanayinin çoğaltıcı etkisiyle önemli bir sosyo-ekonomik gelişim yaşamıștır. Ancak özellikle 1980'li yıllardan sonra petrol sanayisinin istihdam yaratic1 etkisi kaybolmasına rağmen kent, terör olaylarının da etkisiyle çok yoğun göç almıştır. $\mathrm{Bu}$ süreçte yaşanan çarpık kentleşme, Batman'ın modern ve sağlıklı bir kent hüviyetini kazanmasını engellemiş ve kentleşme süreci tamamlanamamıştır. Plansız ve istihdam temelli göç akınına dayanmayan kentsel büyümeden en fazla verimli tarım arazileri etkilenmiştir.

Nitekim kent verimli Batman ovası üzerinde gelişmiş, kentsel büyüme tamamen kuru ve sulu tarım arazileri ile otlak/mera ve yeşil alan vasfindaki nitelikli arazilerin yerleşemeye dönüştürülmesi şeklinde gerçekleşmiştir. Batman kentinin 1985 ve 2016 yıllarına ait uydu görüntüleri temel alınarak yapılan analizler neticesinde, kentin 30 yıllık süreçte 1730 hektar büyüyerek, yaklaşık \% 167 oranında mekânsal genişleme sağladığı anlaşılmaktadır. Bu süreçte kent her yıl çevresine doğru ortalama \% 6'lık bir büyüme gerçekleştirmiştir. Buna karşın kuru tarım arazileri ise 30 y1llık süreçte yaklaşık 2400 hektar azalmış ve \% 20’ye yakın bir kayıp yaşamıștır. Benzer bir durum otlak/mera arazisi için geçerli olup, bu süreçte söz konusu arazilerde 900 hektarlık bir kayıp gerçekleşmiştir. Aynı şekilde yaklaşık 400 hektarlık sulu tarım arazisi ile yeşil alan arazisi de niteliğini kaybederek, yerleşme sınıfına dâhil edilmiştir.

Genel anlamda Batman kentindeki arazi sınıfları değişimi incelendiğinde, kentsel gelişimin amaç dışı arazi kullanımı şeklinde olduğu ve arazi 
kullanım sınıfların önemli değişimlere yol açtığı görülmektedir. Planlı kentleşme ilkelerine aykırı olan bu durum aynı zamanda önemli ekolojik ve doğal ortam sorunlarının ortaya çıkmasına yol açmaktadır. Bilindiği üzere ovalık sahalar üzerinde kurulan yerleşmelerde deprem riski ve zemin problemleri ortaya çıkmakta ve bu da yapılaşma açısından büyük bir risk barındırmaktadır. Batman kentinin ova üzerinde mekânsal büyüme gerçekleştirmesi bu açıdan riskli bir durum oluşturmaktadır. Bunun yanında su kaynaklarının yakınında kurulan kentler, her zaman bu kaynaklar için bir kirlilik kaynağı olmakta ve bu durum çevredeki tarım arazileri için de riskler barındırmaktadır. Batman Çayı'nın hemen kenarına kurulmuş olan Batman kenti, kentsel katı, sıvı ve gaz atıklar tarafindan kirletilmekte ve sulama amaçlı tarım arazileri söz konusu suyu kullandığı için benzer bir kirlilikle karşı karşıya kalmaktadır. $\mathrm{Bu}$ durum insan sağlığı ve ekolojik yaşam için önemli sorunların ortaya çıkmasına yol açmaktadır. Aynı şekilde kent çevresindeki yeşil alanların kentsel kullanıma dönüştürülmesi, Batman gibi yaz mevsiminin çok sıcak geçtiği kentler için hem serinletici kent havasının oluşumunu engellemekte hem de biyoçeşitlilik için önemli bir tehlike oluşturmaktadır. Söz konusu olumsuz durumları en aza indirmek için kent içi ve çevresindeki yeşil alanları ve bitki örtüsünü korumak ve bu alanları artırmak için gerekli çalışmalar yapılmalıdır. Bunun yanında ekolojik ortamın kirlenmesine yol açan kirlilik kaynaklarının bertaraf edilmesi tarımsal arazi kullanımı için oldukça önemlidir.

Sonuç olarak hem ekolojik hem de ekonomik ve sosyal anlamda tüm dünyanın hızla birbirine sık1 sıkıya bağlandığı günümüzde, arazinin doğru ve uygun kullanımı da büyük önem taşımaktadır. Özellikle tarım alanlarının hızla daralması hızla artan dünya nüfus için bir tehdittir. $\mathrm{Bu}$ nedenle Türkiye'nin verimli tarım arazilerinin bulunduğu kentlerden biri olan Batman'da kentleşme çok daha planlı ve doğru yapılmak zorundadır. Bu bakımdan kentler büyürken çevreye verdikleri zararın yanı sıra fark edilen hatalardan dönülmesi çok zor ve maliyetlidir. $\mathrm{Bu}$ nedenle uydu görüntülerinin uzaktan algilama ve CBS teknikleri kullanılarak yapılacak olan kentsel gelişim analizleri yardımı ile yeni planlamalarda geçmişteki hataların tekrarının önlenmesi ve doğru kararlar alınması bakımdan büyük fayda sağlayacaktır.

\section{Kaynaklar}

Adhikari, A., Hansen, J.A., 2018. Land use change and habitat fragmentation of wildland ecosystems of the North Central United States. Landscape and Urban Planning, 177: 196-216.
Akın, O., 2012. İstanbul kentinin değişim öyküsü. Mimarist, 12(45): 46-59.

Alaeddinoğlu, F., 2010. Batman şehri, fonksiyonel özellikleri ve başlıca sorunları. Doğu Coğrafya Dergisi, 24: 19-42.

Aliağaoğlu, A., Uğur, A., 2016. Şehir Coğrafyası. Nobel Yayınevi, İstanbul.

Alkan, A., Adıgüzel, F., Kaya, E., 2017. Batman kentinde kentsel 1sınmanın azaltılmasında yeşil alanların önemi. İstanbul Üniversitesi Edebiyat Fakültesi Coğrafya Dergisi, 34: 64-76.

Anonim, 2018. Batman Kenti Nüfus İstatistikleri. (https://biruni.tuik.gov.tr/medas/?kn=95\&locale= tr,https://biruni.tuik.gov.tr/nufusmenuapp/menu.zul), (Erişim tarihi: 11.04.2018).

Anonymous, 2018. Global Visualization Viewer, (https://glovis.usgs.gov/app?fullscreen=0), (Erişim tarihi: 26.06.2017).

Aydın, O., 2015. Karmaşık kent sistemi, kentsel büyüme kavramlarının anlaşılması ve kent modelleme teknikleri. Türk Coğrafya Dergisi, 64: 51-60.

Bayar, R., Karabacak, K., 2017. Ankara ili arazi örtü değişimi (200-2012). Coğrafi Bilimler Dergisi, 15(1): 59-76.

Benek, S., Şahap, A., 2016. Uzaktan algılama ve coğrafi bilgi sistemleri kullanarak şehirsel gelişimin arazi kullanımına etkisinin incelenmesi: Şanlıurfa şehri örneği. Turkish Studies International Periodical for the Languages, Literature and History of Turkish or Turkic, 11: 79-102.

Çavuş, C.Z., 2007. Çanakkale'de kentsel gelişimin uzaktan algilama ve gps ölçümleri ile izlenmesi. İstanbul Üniversitesi Edebiyat Fakültesi Coğrafya Bölümü Coğrafya Dergisi, 15: 44-58.

Dengiz, O., Demirağ Turan, İ., 2014. Uzaktan algilama ve coğrafi bilgi sistem teknikleri kullanılarak arazi örtüsü / arazi kullanımı zamansal değişimin belirlenmesi: Samsun Merkez ilçesi örneği (19842011). Türkiye Tartmsal Araştırmalar Dergisi, 1(1): 78-90.

Gürün, D., Doygun, H., 2006. Kahramanmaraş kentsel gelişiminin tarımsal alan kullanımı üzerine etkileri. 4. Coğrafi Bilgi Sistemleri Bilişim Günleri, Bildiriler Kitab1, 13-16 Eylül, İstanbul, s. 57-65.

Inouye, C.E.N., Sousa, W.C., Freitas, D.M., 2015. Modelling the spatial dynamics of urban growth and land use changes in the North Coast of Sao Paulo, Brazil. Ocean \& Coastal Management, 108: 147-157.

Kara, F., Karatepe, A., 2012. Uzaktan algilama teknolojileri ile Beykoz ilçesi (1986-2011) arazi kullanımı değişim analizi. Marmara Coğrafya Dergisi, 25: 378-389.

Karakuyu, M., Karaburun, A., Kara, F., 2012. Kentleşmenin Büyükçekmece Gölü havzasındaki arazi kullanım değişimleri üzerindeki etkisinin zamansal analizi. Marmara Coğrafya Dergisi, 26: 4254.

Kaya, Ö., Toroğlu, E., 2015. Kayseri’nin şehirsel gelişiminin izlenmesi ve değişim analizi. Türk Coğrafya Dergisi, 65: 87-96. 
Keleş, R., 1961. Şehir ve Bölge Planlaması Bakımından Şehirleşme Hareketleri. Ankara Üniversitesi Siyasal Bilgiler Fakültesi Yayını, Ankara.

Keleş, R., 2013. Kentleşme Politikası. İmge Kitapevi, Ankara.

Kizılelma, Y., Karabulut, M., Gürbüz, M., Topuz, M., Ceylan, E., 2013. Niğde şehri ve yakın çevresinin zamansal değişiminin uzaktan algılama ve CBS kullanılarak incelenmesi. Journal of World of Turks, 5(3): 21-34.

Özcanl1, M., Özçağlar, A., Özgen, N., Benek, S., 2018. Diyarbakır şehrinin alansal gelişimi ve tarım arazileri üzerindeki etkileri. Akademik Sosyal Araştırmalar Dergisi, 64: 34-42.

Öztürk, D., Şişman, A., Maraş, E.E., Şişman, Y., 2010. Samsun-Atakum'da arazi kullanımi/arazi örtüsündeki değişimlerin uzaktan algılama ve CBS ile belirlenmesi. VI. Ulusal Coğrafya Sempozyumu, Cilt 1, 3-5 Kasım, Ankara, s. 21-29.

Özügül, D.M., 2010. Türkiye'de tarım alanı tahribatı ve çevresel etki değerlendirilmesini yeniden düşünmek. MEGARON Dergisi, 5(2): 91-101.

Seydanlıŏlu, A., Turgut, S., 2017. Türkiye kentleri için kentsel büyüme yönetimi sistemi ve İstanbul örneği. MEGARON Dergisi, 12(3): 429-442.
Sönmez, M.E., 2012. Adana şehrinin alansal gelişimi ve yakın çevresinin arazi kullanımında meydana gelen değişimler. Türk Coğrafya Dergisi, 57: 55-69.

Sunkar, M., Tonbul, S., 2010. Batman şehrinin kuruluşu ve gelişmesi. Istanbul Üniversitesi Edebiyat Fakültesi Coğrafya Bölümü Coğrafya Dergisi, 21: 18-38.

Sütgibi, S., 2008. Türkiye'de yerleşim ekolojisi üzerine bazı değerlendirmeler. Ege Coğrafya Dergisi, 17: 6171.

Tonbul, S., Sunkar, M., 2008. Batman şehrinde yer seçiminin jeomorfolojik özellikler ve doğal risk açısından değerlendirilmesi. Ulusal Jeomorfoloji Sетроzуити, Bildiriler Kitab1, 20-23 Ekim, Çanakkale, s. 103-114.

Tümertekin, E., 1973. Türkiye'de Şehirleşme ve Şehirsel Fonksiyonlar. İstanbul Üniversitesi Yayını No: 1840, İstanbul.

Uzun, A., Demir, Y., 2016. Kentsel saçaklanmanın tarım alanlarına yayılımının uydu görüntüleri yardımıyla belirlenmesi: Samsun örneği, Anadolu Tarım Bilimleri Dergisi, 31: 408-416. 